\title{
THE COMMENTARIES
}

April 2021

Volume: 1, No: 1, pp. $57-64$

ISSN: 2754-8791 (Print) ISSN: 2754-8805 (Online) journals.tplondon.com/com

\section{Minorities in Turkey II: Ideology and Discrimination}

\section{Baskın Oran $^{1}$}

\section{Executive summary}

This article focuses on the ideological roots of the repressive and discriminatory mentality/philosophy that has shaped democracy and minority policies in Turkey. My aim is to analyze the consequences of this mentality, with an emphasis on hate speech and discrimination. To this end, I summarize the consequences of the issues and policies discussed in the previous article, and discuss their future implications for both the state

THE COMMENTARIES EDITOR IN CHIEF Joost JONGERDEN

\section{EDITORS}

Cengiz GUNES

Bahar ŞIMSŞEK

The Commentaries is an initiative by the EUTCC.

\section{EUTCC CHAIR}

Prof Kariane WESTRHEIM,

University of Bergen, Norway

\section{EUTCC SECRETARY GENERAL}

Prof Michael GUNTER,

Tennessee Technological University, USA

\section{EUTCC BOARD MEMBERS}

Dersim DAGDEVIREN, KURDAKAD, Germany

Dr Joost JONGERDEN,

Wageningen University, Netherlands

Dr Thomas JEFFREY MILEY,

Cambridge University, UK

Estella SCHMID, Peace in Kurdistan Campaign, UK and the people of Turkey. I conclude that it is necessary to refer to citizens not through the ethno-religious term Turk, and still less as Muslims, but through the thoroughly territorial term Türkiyeli (of Turkey), and to do all that is necessary to ensure such a transformation in mentality.

The unitary state in Turkey has not gone through the evolution that it has in France. On the contrary, the nation-state established by the Turkish Republic, just as it directly inherited the hierarchy of the millet system with its basis in Ottoman religious discrimination, also both deepened and broadened the

\footnotetext{
${ }^{1}$ Baskin Oran is a professor emeritus of international relations.
} 
nationalist ideology initiated at the time of the Committee of Union and Progress.

It deepened nationalism in the sense that, not only did it lift the autonomy of second-class non-Muslim subjects, it also carried out ethno-religious cleansing against such people. This stance of nationalists, however secular they may be, rests on an ideological mold that the September 12, 1980 junta, carried out in the name of Kemalism, divulged as the Turkish-Islamic synthesis. In this situation, the supra-identity became Turk, or more accurately, Sunni Muslim Turk.

It broadened nationalism in the sense that when the supra-identity changed from Ottoman to Turk, it was understood that the group resisting this, namely the Kurds, would not be assimilated, such that Kurds were declared an enemy of unity and solidarity. And this change created a picture of Turkey wherein other sub-identities, particularly non-Muslims and Kurds, were marginalized.

This situation diminished to a degree with the EU Reform Packages released between 2001 and 2004. Yet this rapid and radical reform process was cut short at the end of 2004. On October 1, 2004, there was an attack at the press conference of the Minority Report. The source of the Report, the Human Rights Advisory Board of the Prime Ministry, was de facto dissolved. ${ }^{2}$ Serious pressures on human and minority rights followed, setting in motion a step-by-step regression. A wave of "street nationalism" enveloped Turkey, including attacks on non-Muslims, killings, and lynch attempts against Roma and Kurds.

As another effect of the Kurdish issue, regulations were set in motion, reflecting in the body of law the growing atmosphere of the country. Making use of Turkish Criminal Code (TPC) Articles 301 and 216, it became easier to silence even the simplest of criticism, on

${ }^{2}$ http://www.baskinoran.com/makale/Minorityreportaffair-RegentJournal.pdf 
the grounds of "insulting Turkishness and the organs of the state" and "provok[ing] hatred and hostility".

In 2005, Turkish Criminal Code, and in 2006, Anti-terrorist Law were changed in ways that greatly restricted freedoms. The scope of "crime of terror" was significantly broadened, and the very definition of "terror" was blurred as much as possible. Press offenses, which within the framework of the EU Reform Packages were converted from prison sentences to monetary fines, again became punishable by imprisonment. The right of defense was restricted, the authority of security forces to use weapons was broadened, and 15-year-olds began to be counted as terror criminals and subjected to the same procedures and treatments as adults. ${ }^{3}$

AKP, the representative of Islamist ideology, early on issued a number of EU Reform Packages and began to pursue a policy that would bring relief to non-Muslims, Kurds, and indeed all Turkish citizens: the Kurdish opening, the Alevi Workshops, the Roma Opening. Yet AKP's ideology of political Islam is far from democratic, and its nature is very amenable to personal whim. Recep Tayyip Erdoğan, after a very short period of time, did a complete reversal and set about changing state policy in the direction of Islaminflected autocracy, calling it "local and national", as opposed to standardized international values.

After the July 15, 2016 military coup attempt, characterized by President Erdoğan as a "great favor from Allah", 4 the ensuing oppression, which aimed at eliminating opposition by using the coup attempt as pretext, marked the beginning of a perilous period, in terms of democracy. In this path, AKP benefitted greatly from the tactic of victimhood. Having previously benefited from the chosen trauma of 1930s Kemalist nationalism not allowing head-scarfed students onto university campuses, when the July 15, 2016 coup attempt occurred, AKP activated, in place of headscarves and students, the image of the FETÖ (Fethullahi) terrorist as a symbol

\footnotetext{
${ }^{3}$ See Sancar and Akgönül, “Türk Ceza Kanunu Md. 301 (eski 159) Değişiklikleri’” p. 743.

${ }^{4}$ http://www.dw.com/tr/erdoğan-istanbulda-açıklama-yaptı/a-19403922.
} 
of victimhood. Such a mindset inevitably paved the way for three forms or chains of related evil: discrimination, hate speech, and hate crimes.

Despite Turkey's significant experience with hate speech and hate crime, which led, for instance, to the mass scandal of September 67,1955 , this name moved into the public radar only in 2007 , with the murder of Hrant Dink. Hatun Tuğluk, the mother of HDP's imprisoned Deputy Co-President Aysel Tuğluk, died and was buried in Ankara. Immediately after the burial, when a group interfered and persisted for some time, entering the cemetery, cursing and shouting such slogans as “We don't bury terrorist bodies here, this isn't an Armenian graveyard", the grieving family had to dig up the grave, wrap the body again in cloth and take the body to a cemevi before eventually bringing it to Tunceli, a district some $800 \mathrm{~km}$ from Ankara. ${ }^{5}$

Minister of the Interior Soylu said that he had not seen, in the video footage, any slogans shouted at the cemetery, but the testimonies of suspects and police reports contradicted this. ${ }^{6}$

The investigation was opened not into "hate crimes" or the crime of "publicly provoking hatred or hostility" (Art. 216/1), but for violating the Law on Meetings and Demonstrations, 7 and the suspects were freed at the first hearing. ${ }^{8}$

When Turkey was founded, its internal dynamics were not sufficient to produce development. Yet intellectuals who received a Western education set out on a revolution from above-that is, a civilizing process to transition from the religious concept of ümmet to the secular concept of nation, changing the law by using the imposing power of the state.

\footnotetext{
${ }^{5}$ http://www.hurriyet.com.tr/aysel-tuglukun-annesinin-cenazesini-gomdurmediler-40578158.

${ }^{6}$ https://www.artigercek.com/bakan-soylu-ya-2-ermeni-mezarligi-yalanlamasi.

${ }^{7}$ http://www.hurriyet.com.tr/nefret-degil-gosteri-sorgusu-40580541.

${ }^{8}$ http://t24.com.tr/haber/aysel-tuglukun-annesinin-cenazesine-saldiranlar-ilk-durusmada-serbest-bu raya-gommeyin-diye-rica-ettik, 458748 .
} 
Naturally, just as in every case of top-down revolutions, there was reaction in society and from below, and there still is today, to this first wave of modernization.

Following this was the second wave of modernization in the early 2000s: EU Reforms Packages. This second wave was initiated by then Prime Minister Ecevit and sustained by Erdoğan in his first years of power, for reasons now very much debated. Things began to change from the system of the West brought about in the monist atmosphere of the 1920s and 1930s to the West of the 2000s-in other words, a pluralist regime.

Today in Turkey there is sufficient legal grounds to punish incidents of hate and discrimination, and thus, to an important degree, to prevent them. But in a period of power that constantly polarizes society, it is not possible to say that the Judiciary has tried to prevent such incidents by implementing the legal grounds (laws, international agreements). The reasons for this can be listed as:

1) In Turkey, the concepts of hate and discrimination have yet to really sink in, and in the Judiciary, they haven't yet at all.

2) Turkey is a country where civil society is still at a very early stage of development, whilst organs and officials that represent the state are, historically, at a maximum in terms of their power to impact society. In such a country, the hate- and discrimination-laced messages of government bodies or officials force people and communities to act in one single direction: that of the ruling official ideology.

3) In the lawsuits of those sectors most subjected to hatred and discrimination, it is quite rare that criminal provisions that possess the potential to effectively prevent hatred and discrimination are actually implemented.

4) As a result of all of this, thanks to the impunity they have enjoyed, those who commit discrimination and hate crimes are emboldened, 
and judiciary power, rather than stopping or at least deterring these incidents, makes possible their repetition.

In other words, a racism that overlaps with culturalism finds itself, in its most innocent state, in the sentence, "they don't live like us".

Usually defined as "loving one's nation and the state", nationalism in Turkey, whether Kemalist-nationalist or Turco-Islamist religious nationalist in orientation, sees minorities as harmful elements, as it is by definition monist.

This hypothesis does serious damage to both the nation and the state in three senses: it prevents the development of democracy, which by its most basic definition means "respect for people/the individual"; it divides the nation; it weakens the state to the outside.

The Turkish nation-state modernized society at a time when Western Europe was still monist (that is, the 1920s and 1930s), and successfully protected the country from the outside in a dangerous environment. Contemporary international law considers the protection of minorities through a four-pronged approach: the protection of the existence of minorities, and their not being subjected to ostracization, discrimination, and assimilation. ${ }^{10}$

The Turkish nation-state has implemented precisely the opposite of these principles: it has denied the existence of minorities, and has ostracized them and subjected them to discrimination and assimilation. In particular, it has insured that discrimination and assimilation, the two major forms of divisiveness, walk hand in hand.

In the 2010s, the Erdoğan administration has revived the monist and nationalist policies of the 1930s' nation-state, despite that nearly a century had passed, and has used them to Islamify and Turkify society. From the perspective of 2021, what Erdoğan did in the 2010 s

\footnotetext{
${ }^{9}$ Nilay Vardar's expression: https://bianet.org/bianet/toplum/149277-mevzubahis-romanlarsa. ${ }^{10}$ Bay1r, Minorities and Nationalism in Turkish Law, p. 8. 
consists of painting green the monist methods of the 1920s and 1930s.

As a result of the monist approach of both these nationalisms, the nation-state in terms of regarding as "prospective citizens", de facto classifies and divides Turkish citizens, in a top-down manner, by a four-part hierarchy:

a) Hanefi, Sunni, Muslim Turks. They are always at the highest. Of course, secular nationalism (Kemalist nationalism) adds the adjective laic to this historical characteristic: a prospective citizen should, in addition to Hanefi, Sunni, Muslim, and Turk, also Laic: LAHASÜMÜT.

This LAHASÜMÜT changed in a way that increased following the point when AKP abandoned its short-lived EU reformism and passed to an Islamist One Man rule; its first syllable was removed, yielding HASÜMÜT (Hanefi, Sunni, Muslim, Turk).

b) Those who are Muslims but not Turks. These are groups subjected to assimilation. For instance, Pomaks, Bosniacs, Circassians, Laz, and so on, though they are not of Turkish lineage, are in the second spot on account of being "Muslims tied to Turkish culture".

c) Kurds. Because they are Muslims who openly reject assimilation, they are in second to last.

d) Non-Muslims. Because their assimilation is considered impossible, they are in last place, and efforts have been made to have them leave the country ("Love It or Leave It"), or, as is now the case, to have them remain in a symbolic, folkloric number.

As a result of this knot of contradictions, the transition in Turkey from the National Security State to the Human Rights State has been delayed significantly, and has grown into a major problem. The happiness of individuals and the nation, and thus the state's future, have become quite convoluted. 
The first wave of modernization succeeded in one major change: the transition from the Feudal State (representing the Empire) to the Nation-State, and the step-up from subject to citizen. This is such a major change that it can only be captured by such terms as mutation or transformation.

At the same time, though, an important proportion of these citizens are "obligatory citizens", because their sub-identity is denied. They stay here because they were born in this country and lack the opportunities to go elsewhere.

Such a citizen is unhappy, and can be a danger to the state. Since there can be no such solution as stationing in everyone's head a soldier with a bayonet, the only sensible path is to ensure that these citizens become "voluntary citizens". And for this, it is necessary to refer to citizens not through the ethno-religious term Turk, and still less through the term Muslim, but through the entirely territorial term of Türkiyeli (of Turkey), and to do all that is needed to ensure this. 